\title{
The Difficulty to Stabilize Energy Markets
}

\author{
Òscar Mascarilla ${ }^{a}$ \\ Universidad de Barcelona \\ Yuri Yegorov $^{b}$ \\ University of Vienna

\section{Montse Crespi-Vallbona ${ }^{c}$} \\ Universidad de Barcelona
}

\begin{abstract}
Energy is one an important class of traded commodities. The particular feature of energy is that about $85 \%$ of energies consumed are produced from non-renewable sources. While the structure of energy market is complex, in general we have competitive markets. Some exceptions like OPEC cartel in fact work now towards stabilization of market for oil, with periodical adjustment in production to keep prices within acceptable corridor. It is important to understand that not only real energy but also paper ener-

a Universidad de Barcelona. Facultad Economía y Empresa. Departamento de Teoría Económica. Diagonal núm. 690 - 08034 Barcelona. omascarilla@ub.edu

Dr Oscar Mascarilla knowledges the financial support of the Spanish Ministry of Science and Technology provided by the project CICYT ECO2008-04997".

b University of Vienna, Faculty of Business, Brunner Strasse, 72, A-1210, Vienna, Austria. yegorov60@gmail.com

c Universidad de Barcelona. Facultad Economía y Empresa. Departamento de Organización de Empresas. Diagonal núm. 690 - 08034 Barcelona. mcrespi@ub.edu

Recibido: julio de 2010. Aceptado: septiembre de 2010.
\end{abstract}


gy (like future contracts and options) are traded. The aim of the article is to analyse the main recent events to understand the specifics of energy markets and macroeconomic externalities derived from price instability, as well as to point towards some solutions to stabilise markets and trends within the current economic crisis.

Keywords: Energy markets, commodities, volatility prices

JEL Classification: C51, G13, Q56

\section{RESUMEN}

La energía es una de las principales commodities comercializables, cuya particularidad es que entorno al $85 \%$ de la energía consumida es producida con recursos no renovables. La estructura del mercado energético es compleja y en general sujeta a mercados competitivos y a precios volátiles. Existen excepciones como el cartel de la OPEP que dota el mercado de una estabilidad de precios ajustando periódicamente la producción, a pesar que en los últimos años ha florecido el comercio de contratos estructurados «energía de papel» (futuros y opciones) que ha conllevado sobrereacciones y volatilidad de precios.

El objetivo del trabajo es analizar los hechos recientes en este mercado en aras a entender sus especificidades propias y las externalidades macroeconómicas que se derivan de la inestabilidad de precios apuntando algunas soluciones preventivas de nuevas crisis energéticas

Palabras clave: Mercado energético, commodities, volatilidad de precios

Clasificación JEL: C51, G13, Q56

\section{INTRODUCTION}

The main traded primary energies include crude oil, natural gas and coal. Electricity is secondary energy and can be produced from both renewable (hydro, wind, etc) and non-renewable sources. It is less important for international trade, with international trade substantially lower than production, and that is why we will not consider it, but focus on oil, gas and coal.

Since primary energies have very heterogeneous distribution in the world (see Fig.1 for reserve-production ratios for oil), and the international trade flows represent a substantial fraction of production with the tendency to grow in future. That is why price stabilization in the world energy markets represents one of the policy objectives. 
In the years 2007 and 2008, the discussion in this market focused on the deep consequences of energy and raw material price increase on consumers and inflation as well as its global impact on trade patterns and the international monetary system, since commodities had become an investment asset replacing financial ones. However, with the crisis becoming deeper, we have seen a dramatic decline of agricultural, mineral and energy commodity prices since 2008.

In the following, the price evolution and instability in the energy markets in the last years are analysed, as well as the difficulty to stabilise the global energy market. Excessive market volatility produces negative externalities for both producers and consumers and is partly responsible for macroeconomic crisis. In this respect, we will also talk about what can be done to stabilise the market. Finally, some perspectives and different conclusions are given.

\section{InStability of the Energy Market. Forces Driving ENERGY MARKETS}

The prices of energies have experienced some considerable volatility in the last years. With the outbreak of the crisis in autumn 2008 and its deepening since 2009, we have seen a dramatic evolution of nominal prices in a considerable number of agricultural, mineral and energy commodities. Historically, they had been keeping a low price pattern in real terms and even followed a downward trend in the 1980s and 1990s. However, the price oscillation between 2008 and 2009 was unprecedented, in part due to financial innovation that has increased the depth (see Fig.2). In section 4 we will try to understand the microeconomics of instabilities through the present functioning of financial markets.

We need to understand how the markets for energy work, and what drives the prices. Classical microeconomics considers static markets and focuses on differences between perfect competition, oligopoly and monopoly. Indeed, we have such cartels like OPEC, and in 1970-80s it was partly responsible for peaks in prices associated with oil crisis. However, at present its role is positive and it tends to stabilize markets by reducing output when prices are falling (see Fig. 3).

It is necessary to distinguish between pricing mechanisms and the underlying forces, which determine prices, or, in other words, to distinguish between how prices are determined and what determines prices. The first is about the organisation of trade, exchange and marketplaces, including access, and the ways prices are negotiated, communicated and made public. This does not necessarily give an insight into what influences decision-making by buyers and sellers, nor about the resulting market balance and price level. Oil and gas have many characteristics that distinguish them from 
other commodities, such as: high uncertainty linked to resource development and the high specificity of investment, the finiteness of the resource, the often highly inelastic demand for energy and its interaction with concentration and capacity restrictions on the supply side, market imperfections such as unavoidable externalities [1,p.42]. The underlying structure of oil and gas trade has an influence on pricing mechanism. We need to use multidisciplinary approach also taking into account such factor as finiteness of resources and the role of spatial factor in price formation (section 3).

There are two different approaches to the economy of finite resources. The Ricardian approach does not emphasise the limits on resources, but rather focuses on the recognition that, as resources become more difficult to exploit, their development requires greater capital spending and technological development, and that a resource rent results only from cost differences between different production sites. This approach is often used as a justification for a cost-based energy pricing system. US economist Hotelling (1931) assumed finiteness of a given resource and investigated the consequences for the inter-temporal optimisation of resource development. Hotelling's theorem claims that the depletion path for a finite resource will be such that the annual revenue follows the interest rate, and that the resulting price path is such that an alternative (backstop technology) will be an economic substitute when the finite resource is depleted [1, p.45].

FIGURE 1.-Reserve-production ratios for oil. We see not many important producers in the world and high variation in $\mathrm{R} / \mathrm{P}$ ratios that will cause less competition in future as resources will dry.

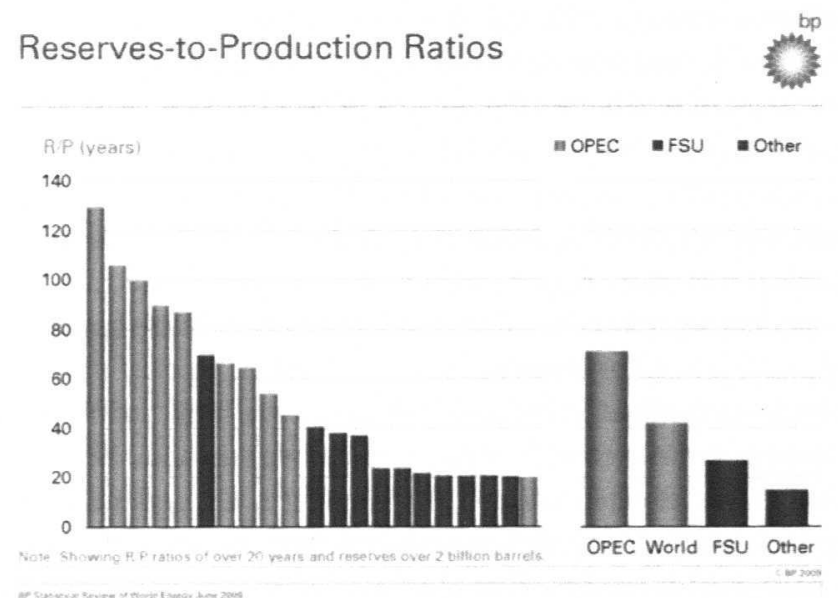

Source: BP Statistical Review 2009. 
FIGURE 2.-In year 2008, we observed huge peak in prices of all primary energies.

\section{Energy Prices}

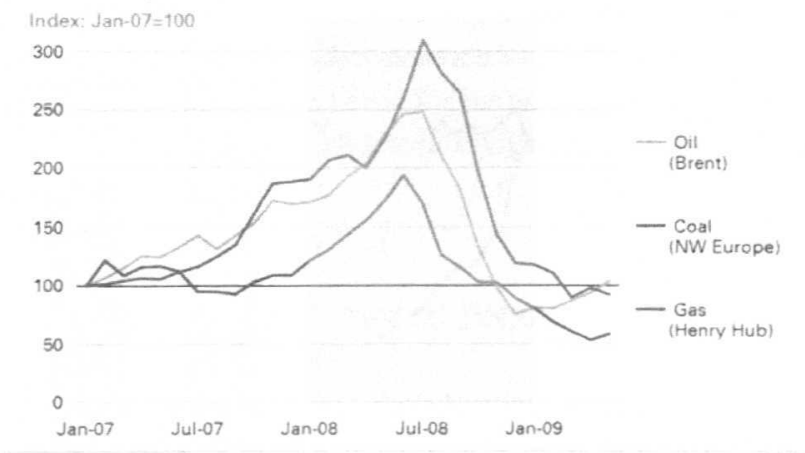

FIGURE 3.-OPEC policy tends to balance production with consumption. This should stabilize market

OPEC Adjusts to Falling Consumption

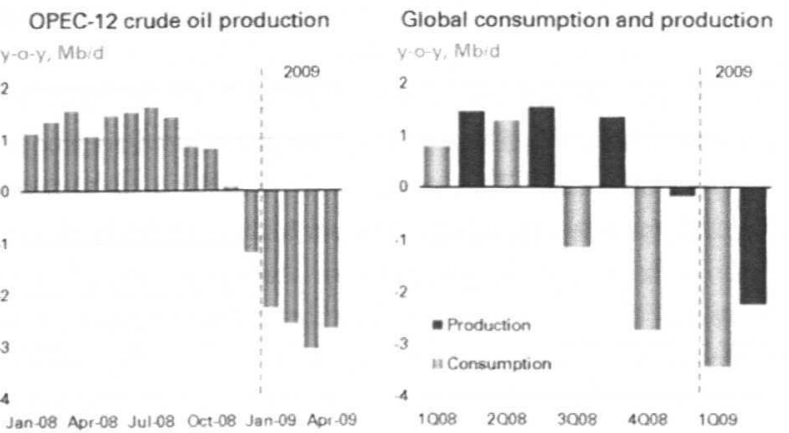

Source: BP Statistical Review 2009 
FIGURE 4.-Prices for natural gas are regional in nature because transport cost is substantially higher than for oil. The peaking here comes not from market clearing procedure at regional markets, but more due to price formula, using lagged oil price

\section{Natural Gas Market}

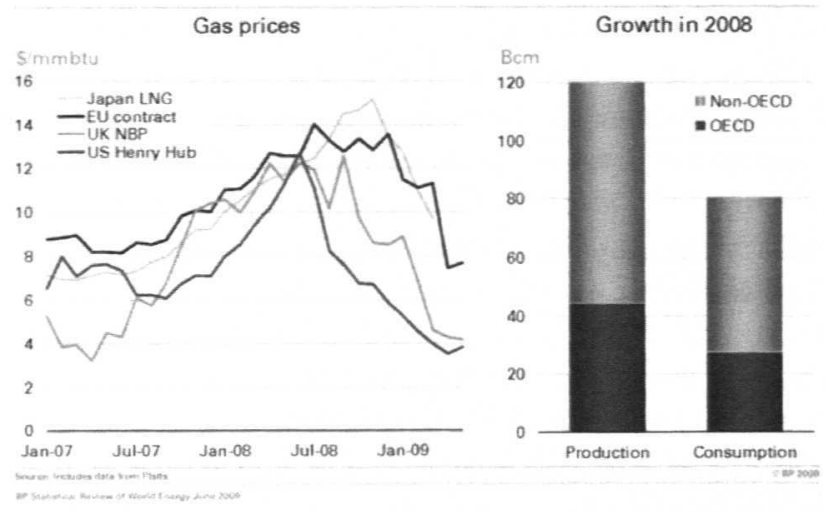

Source: BP Statistical Review 2009.

There are many forces driving the stability of energy markets. Apart from the finiteness of resources for non-renewable energy and contrast between Ricardian and Hotelling rent, we need to take into account spatial (section 3) and temporal (section 4) factors. They represent two alternative self-organizing forces. While an arbitrage on spatial markets is costly (it involves shipping cost and thus bring heterogeneous spatial pattern, at least for bulky goods, with low price/weight ratio), the temporal arbitrage has negligible cost, due to the development of global financial markets with such instruments as futures and options. Thus, money can flow across periods virtually at no cost (except for time discount). This capital inflow can be substantially larger than volume of physically traded good. Thus, we have to distinguish between trade in paper oil and real oil, with the first trade having sometimes much larger volumes. The free flow of short term speculative capital can often have destabilizing effect and increase volatility in energy prices ${ }^{1}$. On the other hand, long term contracts (like those typical

1 The recent $10^{\text {th }}$ IAEE European conference (Vienna, 7-10 September 2009) had a special plenary session on "Energy, speculation and financial crisis", with Fatih Birol (IEA Chief economist) and Georg Erdmann (IAEE President), keynote speakers, discussing this issue. 
for gas markets) tend to reduce price volatility. We will consider this issue in more detail in section 4 .

Clearly, different economic market structures also affect price stability. For example, agricultural markets are driven by perfect competition market patterns, with many sellers but no effect on the global market for that particular product. Contrary, the energy and mineral markets come close to an oligopolistic or oligopsonistic market. In these cases, the decisive point is whether producers usually depend heavily on selling, which may induce them to try and sell even higher amounts in the light of price reductions, but also if the commodity is contracted through one or several exchange markets acting as a monopsony or oligopsony.

\section{Spatial Factors in Energy Markets}

Historically, space and geography played more important role in formation of pricing pattern than today. With the development of transport technologies and reduction of tariffs a possibility to have unique world price for particular goods have emerged. Indeed, a century ago delivery costs of all goods was a significant fraction of their price, leading to substantial spatial price variation. Today international price variation for hi-tech goods no longer depends on geography, but more on differences in tariff policies. Agricultural goods had clear spatial price pattern a century ago, driven by heterogeneity in climatic conditions, demand density and substantial transport cost. The emergence of stock exchanges where these commodities can be traded had a positive role of risk diversification for consumers (who no longer became dependent on bad weather in particular region) and formed world price. Along with the reduction in relative weight of transport cost this brought a unique world price ( or London).

For instance, the production cost for gas, cement or wood is close to their shipping cost, so there will be a relevant price spread according to the country. However, in the case of oil, the price will rather depend on the crude type (WTI, OPEC, Brent, etc.) and its refinement cost, and not so much on the shipping cost, which is relatively low.

If we concentrate on primary energies, we can conclude that gas and coal has regional price pattern (due to substantial role of transport in total cost). Looking at Fig.3, we see that regional prices for gas coevolve, but at any time cross-regional differential is substantial. It cannot be fully eliminated despite the existence of spatial arbitrage opportunity, due to high transport cost. Note that practically all natural gas available 
for spatial arbitrrage comes from LNG technology, which requires much higher investment than oil. While for sea transport of oil we need only tankers, for cross-sea delivery of natural has we need special cryogenic vessels along with costly liquefaction and regasification plants on the coast.

\section{The Role of Financial Markets in Price (De)Stabilization}

Initially, energy has been traded only on spot markets with physical delivery. Oil trade started in 1859 in Pensylvania (US). The volatility of the early days came from heterogeneity in production, due to depletion of old fields and new discoveries in random moments. Before 1970s, only spot markets for oil existed, and most of contracts (especially those served by OPEC countries) have been long term. [1, ch.3] Future markets for crude oil were formed in 1973. The initial objective of forward and future markets was to reduce price volatility. However, speculation also takes place in the forward market. A cargo of crude oil can be transferred from one trader to another many times between loading and delivery [3, p.80].

The futures for natural gas emerged in 1990 at NYMEX. At present, there exists two types of trading energy: with physical delivery (physical) and without it (financial). At present, trade in oil futures substantially exceeds the volume of physical trade. In 2007, about $1 / 4$ of WTI (brand of crude) future positions at NYMEX have been hold by non-commercials, or speculators [3, Fig.14].

Option is another financial instrument. It first appeared in financial markets, but later moved to commodity markets. Other financial instruments can be produced from futures and options; they are called financial derivatives. When the capital accociated with derivatives substantially exceeds one associated with stocks, market volatility can be generated by market itself. There was a tendency of growth of the volume of derivatives relative to the volume of stocks in all markets. Some researchers believe this to be one of the reasons for present financial crisis.

Volatility has been always associated with oil markets. The paper of Wirl [2] represents a good survey and a bunch of mathematical models that can partly explain this phenomenon. However, they do not give explanation to the recent positive trend in oil prices (2000-2008), that ended in price peak in July 2008 (above $140 \$ / \mathrm{brl}$ ) followed by its collapse (to $40 \$ / \mathrm{brl}$ ). The presentation of Haas [3] reveals a potential mechanism for this phenomenon. First, it is well known that oil market is characterised with inelastic demand in the short run, and in certain conditions with inelastic supply. If we draw these curves on graph, it is easy to see that small shifts in demand cause substantial 
shift in equilibrium price. Next, he looks at the effect on financial speculative capital on demand. When price rises, the capital inflow shifts demand to the right, and price rises more. Contrary, at the period of price decline, speculative capital moves away, shifting demand curve to the left, with equilibrium price falling. Such mechanism can explain very sharp rise in oil price in the first half of 2008, followed by sharp decline of this price in the second half of 2008.

\section{Evolution of Prices}

The prices of energies have declined in real terms in relation to the peak reached in the late 1970s. They did so quite strongly up to 2000 , when they reached their minimum. The price increase between 2001 and 2008 was approximately $135 \%$. Some reasons for this are the demand of Asian economies for these goods, especially the rise of China as the international economy, as well as the reduction of the offer in the course of the advent of bio-fuels and adverse climatic conditions.

It is also true that the market overreacts out of three reasons: excessive global liquidity, i.e. lack of monetary policies and its effect on interest rates, the dollar effect, and finally speculative liquidity coming from other markets such as stock and property.

The interest rate evolution during 2005-2008 has manifested itself in at least three ways:

- Increasing incentives for present versus future output,

- Increasing the opportunity cost of companies to keep stocks,

- Encouraging speculators to take positions in commodity contracts.

In all three channels we find a negative association between interest rates and commodity prices in real terms. Also, the price evolution can correlate with the ongoing depreciation of the dollar as compared to the euro in the 2003-2008 periods (Fig 5). The underlying idea of the dollar effect is that changes in the real value of the US currency imply fluctuations in international relative purchasing power. Thus, a depreciation of that currency means less purchasing power in terms of energies in the dollar zone. 
FIGURE 5.-Evolution of the dollar and commodity price volatility. 2003-2008.

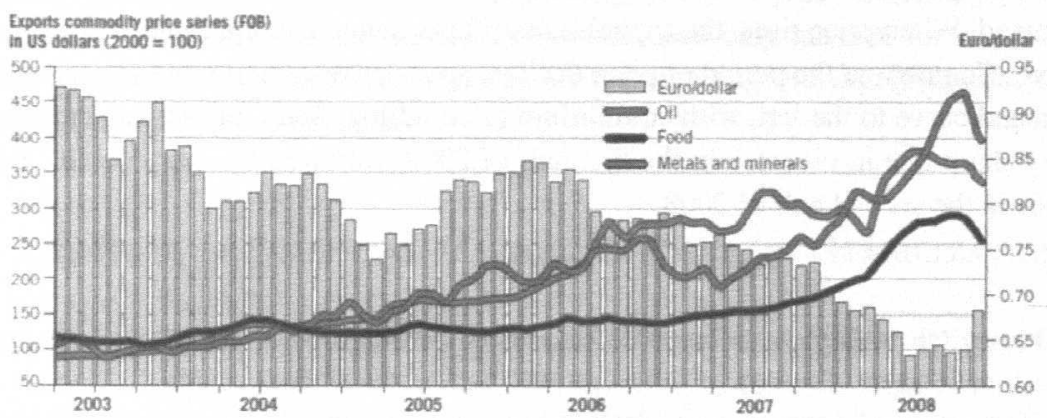

Source: The World Bank's Commodity and own data

Finally, due to downward expectations in the financial and housing markets (which used as an escape for many investors), the year 2008 was dominated by the paper energies market; to be more precise, by the rise of futures negotiated in non-regulated electronic markets, where the volume of traded "paper energy" exceeded real trade flow by factor 20 . This is easily observed with the Bank of International Settlements data that show that toward mid 2008, the total sum of derivatives contracts amounted to 10 trillion dollars, twenty times the 1998 value. Many of these contracts have been part of many investment funds indexed according to the evolution of the oil barrel price and that of other raw materials (mostly related to Goldman Sachs, Morgan Stanley, Citigroup and JP Morgan). All these derivatives have become an option for investors to protect themselves from inflation, and their profitability depended on self-accomplishing expectations, so speculative activity has worked as an amplifier.

In the middle of year 2008, the total sum of derivatives contracts amounted to 10 trillion dollars, twenty times the 1998 value. These derivatives have become an option for investors to protect themselves from inflation.

On the other side, the variability of primary commodity prices has its origin in production and consumption elasticity being low in the short term. That is, the response pace of production is low given the fact that production decisions are often taken before prices are known. These decisions depend on price expectations and not on their realisation ${ }^{2}$.

${ }^{2}$ In the case of agriculture, these realisations can even cause giving up a harvest if the price of collecting it is higher than the total value expected from its sale. 
At the same time, economic stakeholders base their price expectations on the past behaviour of this variable in some of these agricultural markets. Hence the possibility of strong production and price instability comes up, which later dissipates over time as information flows on an ongoing basis between economic stakeholders. However, it may occur that price level and amount available tend to balance: out of a situation in which demand for the product in the initial stage is much higher than the amount offered, it later tends to balance in the medium or long term due to offer and demand pressure. But it may diverge if there are strong price fluctuations, which fosters the absence of a balance point. This interaction process between expectations and reality creates an interplay between price and volume, known as "cobweb model" in economic theory.

Commodity price fluctuations are based on demand shocks (out of industrial cycles linked to metal demand) and offer shocks. The amplitude of commodity price fluctuations in response to offer-related decisions taken with a given anticipation are usually based on and supply shocks. Within this context, the socioeconomic debate has been focusing on the considerable destabilising consequences of the increase of food and raw material prices that are difficult to handle from a national political perspective, which clearly shows a dilemma in social policies.

\section{Macroeconomic Externalities from Energies Price INSTABILITY}

Negative externalities of energies price movements may vary according to the sort of energy and the economy involved. For instance, in developed economies, energies do not represent a significant part of the consumption basket of households, as opposed to less developed economies - specifically, it amounts to only $10 \%$ in Organisation for Economic Co-operation and Development (OECD) countries. Consumption basket of developing countries depend more on raw materials. For example, food amounts to roughly $65 \%$ of the consumption basket in Sub-Saharan Africa and 30\% in Asia, which may bring about food crises and deep macroeconomic imbalances (IMF, 2007).

Also tax revenue is affected by events in these markets, as shows the increasing importance for global finance of Sovereign Wealth Funds (SWF), the origin of which is often associated to public ownership of strategic commodities.

Highly volatile prices create problems in implementing policies to stabilise and reduce dependence on commodities. The idea is that in the increase stage of the price cycle, the economy experiences a rise in exports, tax revenue and production, so there are no political incentives to implement innovative measures aimed at diversifying 
production, even if there are perhaps resources that may allow tackling them. Once prices decline, the political desire for having an influence on commodities will be higher, but there will probably be not enough resources or a favourable context to act accordingly.

However, given the interaction between supply and demand, strategies to stabilise these markets have been traditionally fuelled by a genuine interest of consumers and producers of commodities to protect themselves against the risk of price fluctuation (IMF, 2007). This sort of presence in the futures markets is associated to commercial action of stakeholders interested in the underlying physical asset.

The demand of stakeholders interested in such assets, albeit using speculative methods, would stabilise prices if they created reserves for more difficult times. Their demand would serve as a support against price decline, thus avoiding withdrawal by many producers who could now go on supplying future markets. If abundance turns into scarcity and prices rise, the withdrawn surpluses will reappear and be now sold at a higher price. Markets would stabilise and prices would not surge in the face of any eventuality. In this case, speculation would have a stabilising effect, very different from recent years in which the presence of financial investors has affected the dynamics of price adjustment in a non-linear way, with opposite effect of price destabilization.

It must not be forgotten that according to the sort of commodity, the price will be more or less volatile. For instance, commodities with an oscillating offer due to climate reasons, such as agricultural products, are more volatile than those with a more stable offer, such as energy or minerals. Price stability of the former depends on the existence of substantial storage capacity, so in times of high production output enough reserves are created for periods of low production. Contrary, in the mineral or energy market, with finite and non-renewable goods, price stability is higher, with fluctuations being demand-driven as the output cost is stable. In this respect, it needs to be pointed out that a high rigidity in short-term offer makes prices very unstable, that is, they undergo great variations at the slightest change in demand.

The different market structures also affect stability. Agricultural markets are driven by perfect competition market patterns, with many offers but no effect on the global market for that product. Contrarily, the energy and mineral markets come close to an oligopolistic or oligopsonistic market. In these cases, the decisive point is whether producers usually depend heavily on selling, which may induce them to try and sell even higher amounts in the light of price reductions, but also if the commodity is contracted through one or several exchange markets acting as a monopsony or oligopsony.

Sometimes we have cumulative influence of different factors. For example, the commodity involves a high shipping cost and the supplier has control over distribution at 
regional level. For instance, the output cost for gas, cement or wood is close to their shipping cost, so there will be a substantial price spread across the globe, and prices may differ across countries and regions. However, in the case of oil, the price will rather depend on the crude type (WTI, OPEC, Brent, etc.) and its refinament cost, and not so much on the shipping cost, which is relatively low. Another important point is both national and international spread, which makes it difficult to take coordinated decisions.

\section{CONCLUSIONS AND POLICY IMPLICATIONS}

The financial crisis emerged after explosion of bubbles (financial, housing and commodity). It has caused deflation in energy prices, and the reversal is unlikely to occur in the short term, although long-term demand will contribute to a future price increase.

With global economic deceleration and decreasing demand for raw materials, especially from emerging economies such as China (the biggest consumer in the world), ongoing energy price moderation is expected (despite the fact that have seen substantial recovery of oil price in 2009 , from $\$ 40$ to $\$ 70-80$ per barrel), and stabilisation will be determined by output adjustment. In relation with oil, the OPEC has announced new voluntary restrictions on production. IEA (2009) has revised downwards its forecast on the speed of growth in consumption of different energies across globe in the coming decades.

To summarise, the future evolution of energy markets will still depend on global demand, population growth, bio fuel production, energy prices, economic growth, crop yields and trade policies (tariff restrictions or benefits and direct subsidies ).

This article has analysed the different options to stabilise these markets. The starting point of the problem has to do with the impact of globalisation in energy markets in which the territorial and decision-taking area in politics (the nation state) does not coincide with the territorial area of economics (the market is the world).

In this scenario, international capital movements, especially in the short term, will play a decisive role in financial markets, foreign exchange, the price of energy and others commodities and the effects of national macroeconomic stabilisation policies. However, financial markets themselves have to be reformed in the direction of higher efficiency and higher immunity towards emergence of new bubbles.

With this starting point, it comes out that it is not feasible to keep national sovereignty in conventional terms, have stable markets and fully participate in the globalisation process simultaneously. If every country pretends to act according to its own interests only, a typical prisoner's dilemma will be reached. In fact, this has been an evolution that has led to energy crises and growing instability in the markets over the last two 
years, and this requires some reasonable social political mechanisms of stabilisation, coordination and compensation.

\section{REFERENCES}

Putting a Price on Energy. International Pricing Mechanisms for Oil and Gas. Energy Charter Secretariat, 2007. ISBN: 978-90-5948-047-6.

HaAs ReInhard. What drives the oil price up and down? Demand, physical limits and/or speculation? - Presentation at the 10th IAEE European Conference, Vienna, 7-10 September 2009.

WIRL Franz (2008) Why do oil prices jump (or fall)? - Energy Policy, vol. 36, p.1029-1043.

IMF (2007) «Global Prospects and Policies. World Economic Outlook, Chapter 1.

Sala-I-Martin X., Subramanian A. (2003) «Addressing the Natural Resource Curse: An Illustration from Nigeria», IMF Working Paper, 03/139.

Hotelling H. (1931) The Economics of Exhaustible Resources, Journal of Political Economy. BP Statistical Review 2009.

IEA (2009) World Energy Outlook.

Fernández, M. ${ }^{a}$ A (2006), «El Protocolo de Kioto, un reto para el sistema eléctrico español», Cuadernos de Economía, vol. 29, págs. 141-164,

Mascarilla, O (2009), «La ineficacia de los estados en la corrección de los fallos del mercado mundial», Cuadernos de Economía, vol. 32, núm. 88, enero-abril, págs. 063-080 